\title{
Usefulness of Neutrophil-to-Lymphocyte Ratio in Risk Stratification of Patients With Advanced Heart Failure
}

\author{
Vicente A. Benites-Zapata, MD ${ }^{\mathrm{a}}$, Adrian V. Hernandez, MD, $\mathrm{PhD}^{\mathrm{b}, \mathrm{c}}$, Vijaiganesh Nagarajan, MD, MRCP ${ }^{\mathrm{d}}$, \\ Clay A. Cauthen, MA, MD ${ }^{\mathrm{e}}$, Randall C. Starling, MD, MPH ${ }^{\mathrm{f}}$, and W.H. Wilson Tang, MD ${ }^{\mathrm{f}, *}$
}

\begin{abstract}
Elevated neutrophil-to-lymphocyte ratio (NLR) has been associated with increased mortality in patients with acute heart failure (HF) and neoplastic diseases. We investigated the association between NLR and mortality or cardiac transplantation in a retrospective cohort of 527 patients presented to the Cleveland Clinic for evaluation of advanced HF therapy options from 2007 to 2010. Patients were divided according to low, intermediate, and high tertiles of NLR and were followed longitudinally for time to all-cause mortality or heart transplantation (primary outcome). The median NLR was 3.9 (interquartile range 2.5 to 6.5). In univariate analysis, intermediate and highest tertiles of NLR had a higher risk than the lowest tertile for the primary outcome and all-causes mortality. Compared with the lowest tertile, there was no difference in the risk of heart transplantation for intermediate and high tertiles. In multivariate analysis, compared with the lowest tertile, the intermediate and high NLR tertiles remained significantly associated with the primary outcome (hazard ratio $[\mathrm{HR}]=1.61,95 \%$ confidence interval $[\mathrm{CI}] 1.10$ to 2.37 and $\mathrm{HR}=1.55,95 \%$ CI 1.02 to 2.36 , respectively) and all-cause mortality (HR $=1.83,95 \%$ CI 1.07 to 3.14 and $\mathrm{HR}=2.16,95 \%$ CI 1.21 to 3.83 , respectively). In conclusion, elevated NLR is associated with increased mortality or heart transplantation risk in patients with advanced HF. (c) 2015 Elsevier Inc. All rights reserved. (Am J Cardiol 2015;115:57-61)
\end{abstract}

Lymphocytopenia has long been associated with poor prognosis in heart failure (HF). ${ }^{1,2}$ Several studies over the past few decades have demonstrated the potential of neutrophil-to-lymphocyte ratio (NLR), a widely available hematologic marker of oxidative stress damage, to serve as a good prognostic marker of mortality in cardiac and noncardiac diseases. ${ }^{3-7}$ In this study, we evaluated the association between NLR and future risk of mortality or cardiac transplantation in a large contemporary cohort of patients with advanced $\mathrm{HF}$.

\section{Methods}

We analyzed 549 consecutive patients presented to the Cleveland Clinic (Cleveland, Ohio) from 2007 to 2010 for evaluation of advanced HF therapies and consideration for heart transplantation or mechanical circulatory assist

\footnotetext{
${ }^{a}$ Unidad de Análisis y Generación de Evidencia en Salud Pública, Instituto Nacional de Salud, Lima, Peru; ${ }^{b}$ Faculty of Health Sciences, Postgraduate and Medical Schools, Universidad Peruana de Ciencias Aplicadas, Lima, Peru; ${ }^{\mathrm{c}}$ Health Outcomes and Clinical Epidemiology Section, Department of Quantitative Health Sciences, Lerner Research Institute, Cleveland Clinic, Cleveland, Ohio; ${ }^{\mathrm{d}}$ Department of Cardiovascular Medicine, University of Virginia, Charlottesville, Virginia; ${ }^{\mathrm{e} S e t o n}$ Heart Institute, Kyle, Texas; and ${ }^{\mathrm{f}}$ Department of Cardiovascular Medicine, Heart and Vascular Institute, Cleveland Clinic, Cleveland, Ohio. Manuscript received July 27, 2014; revised manuscript received and accepted October 7, 2014.

This research was supported by National Institutes of Health grant RO1 HL103931.

See page 60 for disclosure information.

*Corresponding author: Tel: (216) 444-2121; fax: (216) 445-6165.

E-mail address: tangw@ccf.org (W.H. Wilson Tang).
}

devices. Electronic medical records were used to obtain demographic variables (age, gender, and race), clinical variables, laboratory values, and medications. Among this cohort, 527 patients had documented values of NLR within the time frame and clinical stability to complete the comprehensive evaluation for advanced HF therapeutics and were included in this study. Mortality data were obtained from social security death index (until 2012) and timing of death and heart transplantation were confirmed by review of the electronic medical records. The construction of the database was conducted by an independent researcher who was not involved in the care of patients. Data were collected retrospectively and the study was approved by the Institutional Review Board of the Cleveland Clinic.

NLR was calculated as the ratio between neutrophil count and lymphocyte count obtained at the time of evaluation. Participants were categorized in NLR tertiles low $(<3.0)$, intermediate (3.0 to 5.4), and high $(>5.4)$. The primary outcome was a composite of all-cause mortality or heart transplantation. Information on heart transplantation was extracted from the electronic records.

Continuous variables were described as mean and SD or median with interquartile range. Categorical variables were expressed as frequencies and percentages. Continuous variables were compared among NLR tertiles with the analysis of variance or Kruskal-Wallis tests; categorical variables were compared with the chi-square test. The Kaplan-Meier method was used to evaluate survival or freedom from events, and the log-rank test was used to evaluate differences among NLR tertiles. Univariate and multivariate Cox regression models were used to assess the association between tertiles of NLR and the primary outcome or its components. We reported crude and adjusted hazard ratios 
Table 1

Baseline characteristics of patients with severe chronic heart failure grouped in tertiles of neutrophil-to-lymphocyte ratio

\begin{tabular}{|c|c|c|c|c|}
\hline \multirow{2}{*}{$\begin{array}{l}\text { Neutrophil-to- } \\
\text { Lymphocyte ratio } \\
\text { Variable }\end{array}$} & \multicolumn{3}{|c|}{ Tertiles } & \multirow{2}{*}{$\begin{array}{c}\mathrm{p} \\
\text { Value }\end{array}$} \\
\hline & $\begin{array}{c}\text { Low } \\
(\mathrm{n}=176)\end{array}$ & $\begin{array}{l}\text { Intermediate } \\
(\mathrm{n}=177)\end{array}$ & $\begin{array}{c}\text { High } \\
(\mathrm{n}=174)\end{array}$ & \\
\hline ge (years) & $53(43-61)$ & $59(51-64)$ & $57(47-64)$ & $<0.01$ \\
\hline Tale & $113(64 \%)$ & $136(77 \%)$ & $134(77 \%)$ & $<0.01$ \\
\hline Black & $42(25.4 \%)$ & $18(11.2)$ & $20(12.7)$ & $<0.01$ \\
\hline Smoke & $47(27 \%)$ & $35(20 \%)$ & $32(18 \%)$ & 0.13 \\
\hline iabetes mellitus & $38(22 \%)$ & $53(30 \%)$ & $46(26 \%)$ & 0.19 \\
\hline Iypertension & $60(34 \%)$ & $81(46 \%)$ & $77(44 \%)$ & 0.05 \\
\hline Dyslipidemia & $74(42 \%)$ & $86(49 \%)$ & $64(37 \%)$ & 0.07 \\
\hline $\begin{array}{l}\text { Non-ischemic } \\
\text { heart failure }\end{array}$ & $113(65 \%)$ & $97(55.4 \%)$ & $100(57.8 \%)$ & 0.20 \\
\hline $\begin{array}{l}\text { Chronic obstructive } \\
\text { pulmonary } \\
\text { disease }\end{array}$ & $15(9 \%)$ & $16(9 \%)$ & $14(8 \%)$ & 0.98 \\
\hline $\begin{array}{l}\text { Coronary Artery } \\
\text { Disease }\end{array}$ & $65(37 \%)$ & $77(44 \%)$ & $84(48 \%)$ & 0.10 \\
\hline Stroke & $13(7 \%)$ & $21(12 \%)$ & $19(11 \%)$ & 0.33 \\
\hline Atrial Fibrillation & $61(35 \%)$ & $67(38 \%)$ & $66(38 \%)$ & 0.76 \\
\hline $\begin{array}{l}\text { Ventricular Assist } \\
\text { Device }\end{array}$ & $34(19 \%)$ & $58(33 \%)$ & $60(35 \%)$ & $<0.01$ \\
\hline Creatinine (mg/dL) & $1.1(0.9-1.4)$ & $1.2(1.0-1.5)$ & $1.3(1.0-1.8)$ & $<0.01$ \\
\hline $\begin{array}{l}\text { Estimated } \\
\text { glomerular } \\
\text { filtration rate } \\
\left(\mathrm{ml} / \mathrm{min} / 1.73 \mathrm{~m}^{2}\right)\end{array}$ & $85(63-111)$ & $81(56-112)$ & $68(48-100)$ & $<0.01$ \\
\hline $\begin{array}{l}\text { Total Protein } \\
\text { (g/dL) }\end{array}$ & $6.9(6.3-7.4)$ & $6.7(6.2-7.3)$ & $6.2(5.3-6.9)$ & $<0.01$ \\
\hline Albumin (g/dL) & $4.0(3.6-4.4)$ & $4.0(3.4-4.4)$ & $3.4(2.8-3.9)$ & $<0.01$ \\
\hline Bilirubin (mg/dL) & $0.8(0.5-1.2)$ & $0.8(0.5-1.5)$ & $1.1(0.7-1.8)$ & $<0.01$ \\
\hline $\begin{array}{c}\text { Blood Urea } \\
\text { Nitrogen } \\
(\mathrm{mg} / \mathrm{dL})\end{array}$ & $20(15-40)$ & $24(19-33)$ & $29(22-38)$ & $<0.01$ \\
\hline Sodium (mEq/L) & 136 (134-139) & $136(134-139)$ & $135(132-138)$ & $<0.01$ \\
\hline $\begin{array}{l}\text { B-type Natriuretic } \\
\text { Peptide (pg/mL) }\end{array}$ & $454(102-804)$ & $498(225-956)$ & $\begin{array}{l}619 \\
(244-1224)\end{array}$ & $<0.01$ \\
\hline Platelets $\left(10^{3} / \mu \mathrm{L}\right)$ & $193(155-$ & 194 & $173(127-223)$ & $<0.01$ \\
\hline $\begin{array}{l}\text { Platelet -to- } \\
\text { lymphocyte } \\
\text { ratio }\end{array}$ & $104(77-134)$ & $157(118-211)$ & $222(152-335)$ & $<0.01$ \\
\hline $\begin{array}{l}\text { Mean Platelet } \\
\text { Volume (fL) }\end{array}$ & $10.5(9.9-11.0)$ & $10.4(9.8-11.2)$ & $10.2(9.7-11.0)$ & 0.21 \\
\hline $\begin{array}{l}\text { Neutrophil-to- } \\
\text { lymphocyte } \\
\text { ratio }\end{array}$ & $2.1(1.6-2.5)$ & $3.9(3.4-4.8)$ & $8.1(6.5-12.4)$ & $<0.01$ \\
\hline Aspirin & $94(5370)$ & $109(62 \%)$ & $94(54 \%)$ & 0.20 \\
\hline Beta-blocker & $8(67 \%)$ & $130(74 \%)$ & $87(50 \%)$ & $<0.01$ \\
\hline $\begin{array}{l}\text { Angiotensin- } \\
\text { converting } \\
\text { enzyme } \\
\text { Inhibitors }\end{array}$ & $101(57 \%)$ & $80(46 \%)$ & $59(34 \%)$ & $<0.01$ \\
\hline Clopidogrel & & & & 0.60 \\
\hline Spironolactone & $85(48 \%)$ & $90(52 \%)$ & 67 & 0.05 \\
\hline Hydralazine & $33(19 \%)$ & $50(28 \%)$ & $50(29 \%)$ & 0.05 \\
\hline Nitrates & $46(26 \%)$ & $53(30 \%)$ & $56(32 \%)$ & 0.45 \\
\hline $\begin{array}{l}\text { Angiotensin II } \\
\text { receptor blocker }\end{array}$ & $21(12 \%)$ & $24(14 \%)$ & $16(9 \%)$ & 0.43 \\
\hline Warfarin & $64(36 \%)$ & $63(36 \%)$ & $62(36 \%)$ & 0.99 \\
\hline
\end{tabular}

Continuous variables are expressed as median (interquartile range).

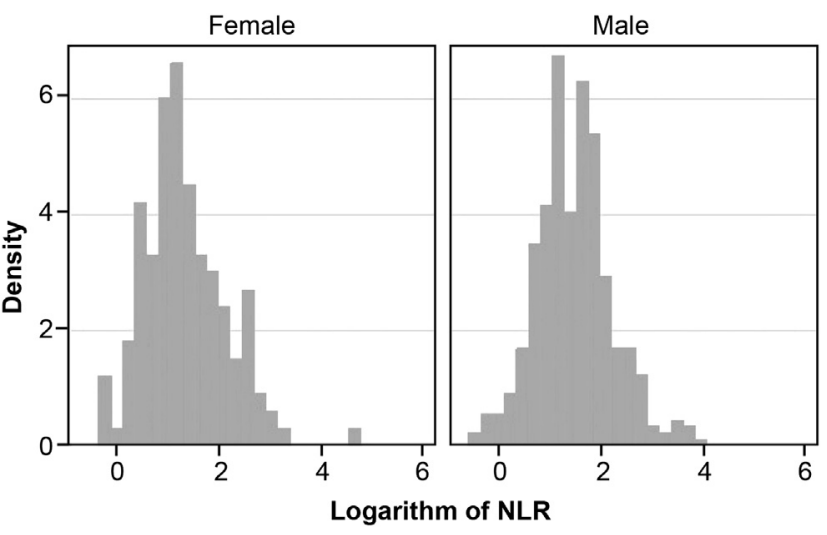

Figure 1. Distribution of NLR stratified according to gender.

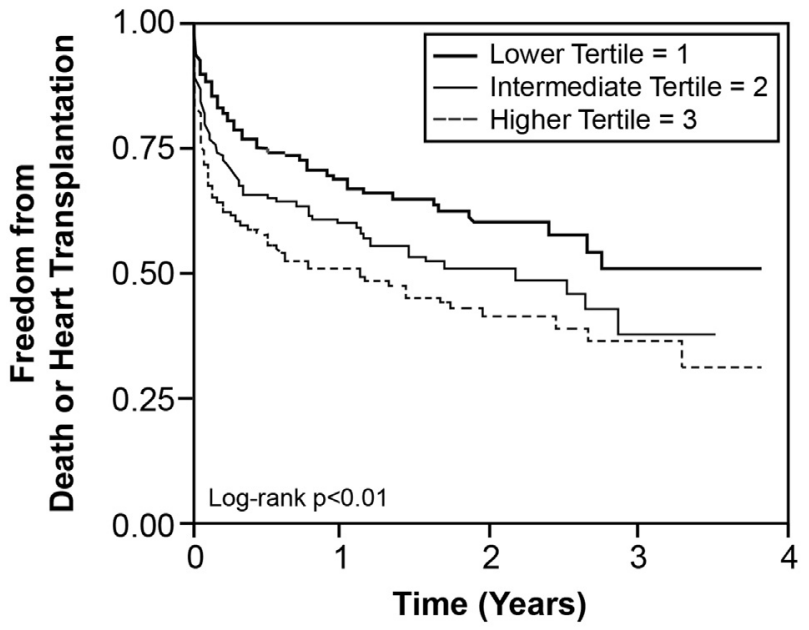

Number at risk

$\begin{array}{llllrl}\text { Tertiles=1 } & 170 & 92 & 39 & 11 & 0 \\ \text { Tertiles=2 } & 167 & 74 & 25 & 3 & 0 \\ \text { Tertiles=3 } & 157 & 64 & 27 & 8 & 0\end{array}$

Figure 2. Kaplan-Meier curves comparing freedom from death or heart transplantation among NLR ratio tertiles in patients with advanced HF.

(HRs) with their 95\% confidence intervals (CIs). Variables with $\mathrm{p}<0.2$ in univariate analysis were considered candidates to enter into the multivariate model along with age, gender, and race. The variable mechanical circulatory assist device was analyzed as a time-dependent variable. Analyses were conducted in STATA version 11.0 (StataCorp LP, College Station, Texas).

\section{Results}

Of the 527 patients, 176,177 , and 174 patients were in the lowest, intermediate, and higher NLR tertile, respectively. Baseline characteristics of the patients across NLR tertiles are listed in Table 1. Overall, NLR correlated directly with B-type natriuretic peptide $(\mathrm{r}=0.14, \mathrm{p}<0.01)$. There was no correlation between NLR and left ventricular ejection fraction, peak oxygen consumption, and hemodynamic variables. The distribution of the logarithm of NLR is presented in Figure 1, stratified according to gender (mean $\pm \mathrm{SD}$, NLR men $5.9 \pm 6.3$ vs women $5.5 \pm 8.4, \mathrm{p}=0.6$ ). 
Table 2

Univariate and multivariate Cox models for the primary and secondary outcomes

\begin{tabular}{|c|c|c|c|c|c|}
\hline Outcomes & NLR Tertiles & Crude HR $(95 \%$ CI) & $\mathrm{p}$ value & Adjusted HR (95\% CI) & $\mathrm{p}$ value \\
\hline \multirow[t]{3}{*}{ All-cause Mortality or Heart* Transplantation } & Higher & $1.93(1.42-2.63)$ & $<0.01$ & $1.55(1.02-2.36)$ & 0.04 \\
\hline & Intermediate & $1.42(1.03-1.96)$ & 0.03 & $1.61(1.10-2.37)$ & 0.02 \\
\hline & Lower & 1 & - & 1 & - \\
\hline \multirow[t]{3}{*}{ All-cause Mortality ${ }^{\dagger}$} & Higher & $2.57(1.72-3.85)$ & $<0.01$ & $2.16(1.21-3.83)$ & $<0.01$ \\
\hline & Intermediate & $1.56(1.01-2.40)$ & 0.04 & $1.83(1.07-3.14)$ & 0.03 \\
\hline & Lower & 1 & - & 1 & - \\
\hline \multirow[t]{3}{*}{ Heart Transplantation } & Higher & $1.05(0.66-1.66)$ & 0.84 & $0.80(0.47-1.43)$ & 0.43 \\
\hline & Intermediate & $1.15(0.74-1.76)$ & 0.54 & $1.10(0.68-1.84)$ & 0.71 \\
\hline & Lower & 1 & - & 1 & - \\
\hline
\end{tabular}

* Adjusted for: Age, sex, black race, cigarette smoker, diabetes, coronary artery disease, atrial fibrillation, ventricular assist device, albumin, bilirubin, blood urea nitrogen, sodium, brain natriuretic peptide, platelets, aspirin, beta-blocker, angiotensin-converting enzyme inhibitors and hydralazine.

$\dagger$ Adjusted for: Age, sex, black race, diabetes, hypertension, No ischemic failure, chronic obstructive pulmonary disease, coronary artery disease, stroke, atrial fibrillation, ventricular assist device, creatinine, estimated glomerular filtration rate albumin, blood urea nitrogen, brain natriuretic peptide, platelets and beta-blocker.

¥ Adjusted for: Age, black race, cigarette smoker, hypertension, dyslipidemia, no ischemic failure, chronic obstructive pulmonary disease, stroke, ventricular assist device, albumin, sodium, mean platelet volume, aspirin, beta-blocker, angiotensin-converting enzyme inhibitors and hydralazine. Model stratified by gender.

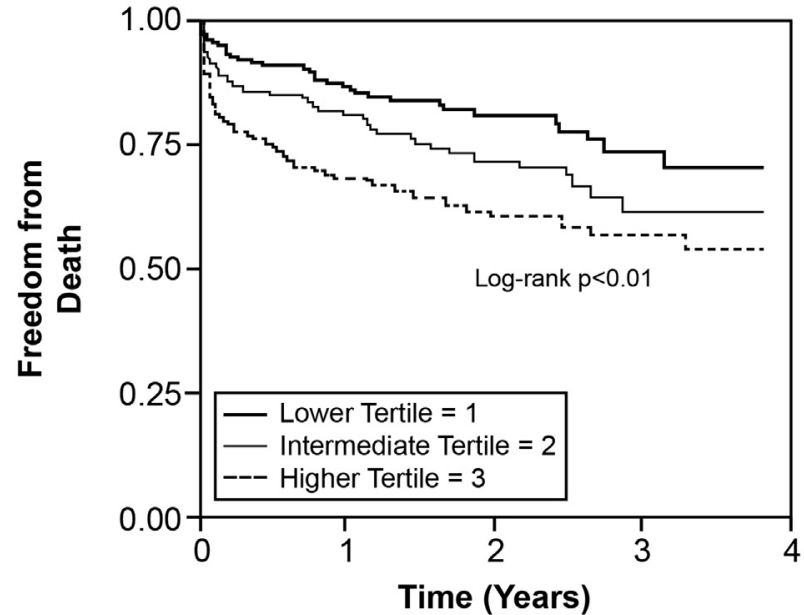

Number at risk

$\begin{array}{lrrrrr}\text { Tertiles }=1 & 175 & 121 & 68 & 25 & 0 \\ \text { Tertiles }=2 & 174 & 112 & 50 & 14 & 0 \\ \text { Tertiles }=3 & 164 & 94 & 54 & 22 & 0\end{array}$

Figure 3. Kaplan-Meier curves comparing survival among NLR tertiles in patients with advances HF.

Over a median follow-up period of 11.3 (interquartile range 3.4 to 21.1) months, the primary outcome occurred in 263 patients $(50 \%), 121$ patients were transplanted (23\%), and 158 patients died during follow-up (30\%). In univariate analysis, NLR was associated with the primary end point ( $p<0.01$, Figure 2). In comparison to the lowest tertile, the intermediate and high tertiles of NLR had higher risk for the primary outcome. In multivariate analysis, and compared with the lowest tertile, the intermediate and highest NLR tertiles were associated with the primary outcome $(\mathrm{HR}=$ $1.61,95 \%$ CI 1.10 to 2.37 and $\mathrm{HR}=1.55,95 \%$ CI 1.02 to 2.36, respectively; Table 2). Compared with the lowest tertile, the intermediate and highest tertiles of NLR had increased risk of all-cause mortality in univariate analysis (Figure 3). In multivariate analysis and compared with the

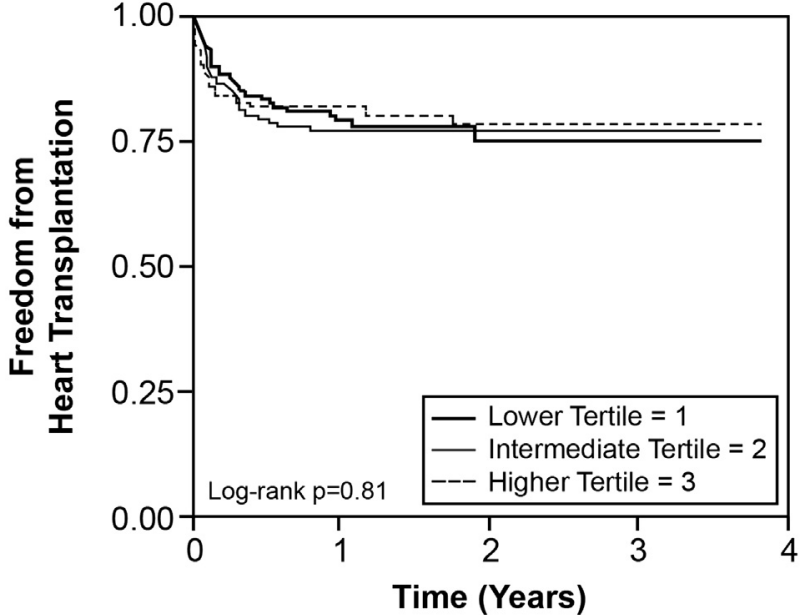

Number at risk

$\begin{array}{llllll}\text { Tertiles }=1 & 171 & 94 & 40 & 11 & 0 \\ \text { Tertiles }=2 & 169 & 85 & 27 & 3 & 0 \\ \text { Tertiles }=3 & 166 & 70 & 28 & 8 & 0\end{array}$

Figure 4. Kaplan-Meier curves comparing freedom from heart transplantation among NLR tertiles in patients with advanced HF.

lowest tertile, the intermediate and high NLR tertiles remained significantly associated with all-causes mortality $(\mathrm{HR}=1.83,95 \% \mathrm{CI} 1.07$ to 3.14 and $\mathrm{HR}=2.16,95 \% \mathrm{CI}$ 1.21 to 3.83 , respectively; Table 2). No association between NLR and heart transplantation was observed in univariate analysis or multivariate analysis (Table 2, Figure 4). We did not find an association between lymphocyte or neutrophil counts with all-cause mortality in models using the same set of confounders of our primary analyses (Table 3 ).

\section{Discussion}

The key finding of this analysis is that patients with advanced HF and higher levels of NLR portend higher mortality or heart transplantation risk. This association was 
Table 3

Multivariate Cox models for the primary and secondary outcomes and neutrophil and lymphocyte tertiles

\begin{tabular}{|c|c|c|c|c|c|c|c|}
\hline Outcomes & Tertiles & $\begin{array}{c}\text { Neutrophil Crude } \\
\text { HR }(95 \% \text { CI })\end{array}$ & $\begin{array}{c}\text { Neutrophil Adjusted } \\
\text { HR }(95 \% \text { CI })\end{array}$ & $\mathrm{p}$ value & $\begin{array}{c}\text { Lymphocyte Crude } \\
\text { HR }(95 \% \text { CI) }\end{array}$ & $\begin{array}{c}\text { Lymphocyte Adjusted } \\
\text { HR }(95 \% \text { CI })\end{array}$ & $\mathrm{p}$ value \\
\hline \multirow{3}{*}{$\begin{array}{l}\text { All-cause Mortality or } \\
\text { Heart Transplantation* }\end{array}$} & Higher & $1.15(0.83-1.60)$ & $1.10(0.74-1.62)$ & 0.65 & $0.45(0.33-0.62)$ & $0.53(0.35-0.81)$ & $<0.01$ \\
\hline & Intermediate & $1.42(1.05-1.94)$ & 1.47 (1.04-2.08) & 0.03 & $0.57(0.42-0.77)$ & $0.63(0.44-0.90)$ & $<0.01$ \\
\hline & Lower & 1 & 1 & - & 1 & 1 & - \\
\hline \multirow[t]{3}{*}{ All-cause Mortality ${ }^{\dagger}$} & Higher & $1.44(0.97-2.14)$ & $1.39(0.84-2.31)$ & 0.20 & $0.59(0.39-0.88)$ & $0.96(0.54-1.69)$ & 0.88 \\
\hline & Intermediate & $1.16(0.78-1.75)$ & $1.05(0.65-1.69)$ & 0.85 & $0.68(0.46-0.99)$ & $0.96(0.60-1.55)$ & 0.87 \\
\hline & Lower & 1 & 1 & - & 1 & 1 & - \\
\hline \multirow[t]{3}{*}{ Heart Transplantation ${ }^{\ddagger}$} & Higher & $0.67(0.38-1.17)$ & $0.56(0.31-1.00)$ & 0.05 & $0.46(0.28-0.76)$ & $0.45(0.26-0.80)$ & $<0.01$ \\
\hline & Intermediate & $1.59(1.03-2.47)$ & $1.64(1.04-2.58)$ & 0.03 & $0.60(0.38-0.94)$ & $0.64(0.33-0.87)$ & 0.01 \\
\hline & Lower & 1 & 1 & - & 1 & 1 & - \\
\hline
\end{tabular}

* Adjusted for: Age, sex, black race, cigarette smoker, diabetes, coronary artery disease, atrial fibrillation, ventricular assist device, albumin, bilirubin, blood urea nitrogen, sodium, brain natriuretic peptide, platelets, aspirin, beta-blocker, angiotensin-converting enzyme inhibitors and hydralazine.

$\dagger$ Adjusted for: Age, sex, black race, diabetes, hypertension, No ischemic failure, chronic obstructive pulmonary disease, coronary artery disease, stroke, atrial fibrillation, ventricular assist device, creatinine, estimated glomerular filtration rate albumin, blood urea nitrogen, brain natriuretic peptide, platelets and beta-blocker.

‡ Adjusted for: Age, black race, cigarette smoker, hypertension, dyslipidemia, no ischemic failure, chronic obstructive pulmonary disease, stroke, ventricular assist device, albumin, sodium, mean platelet volume, aspirin, beta-blocker, angiotensin-converting enzyme inhibitors and hydralazine. Model stratified by gender.

mainly driven by higher all-cause mortality risk, as we did not find association between NLR and heart transplantation after multivariate adjustments. Although NLR may link to mortality like several other conditions, the potential contributory role of NLR in disease progression is not supported by our analysis. Thus, it appears that NLR is more likely a risk marker than the altered composition of leukocytes being a risk mediator for advanced HF.

Several studies of NLR have been carried out in recent years in cardiac and noncardiac diseases. ${ }^{3,4}$ NLR has been studied in acute coronary syndromes in which an increased risk of outcomes was observed in patients with higher values of NLR. Earlier studies in acute coronary syndromes suggested strong prognostic value of NLR associated with mortality risk, ${ }^{8-16}$ whereas short- and long-term prognostic value also extended to those who underwent percutaneous coronary intervention. ${ }^{11,17-20}$ Independently, either neutrophilia $^{21,22}$ or lymphopenia ${ }^{23,24}$ have been associated with increased mortality in acute coronary syndromes and HF, respectively. Indeed, percent lymphocyte is an independent predictor of mortality in the Seattle Heart Failure Model. ${ }^{25,26}$ Interestingly, NLR has been shown to be a better predictor of mortality than independent absolute neutrophil and lymphocyte counts in patients with acute decompensated HF. ${ }^{6}$ There is still no consensus on the cutoff points to define the levels of NLR as most studies categorized into tertiles as we did in our study. In studies of acute cardiac diseases, the median values for the higher tertile of NLR ranged between 6 and 9, where the median of our higher tertile range was found.

Why is NLR a better marker of mortality than absolute lymphocyte and neutrophil count separately? We attribute the strength of the NLR to the fact that it combines 2 different immune pathways: neutrophils are involved with a much quicker response, whereas lymphocytes are related to more adaptive long-term response of the immune system, a synonymous of physiological stress. ${ }^{4}$ Neutrophils produce the enzyme myeloperoxidase that is involved in promoting phagocytic function of neutrophils, but when the levels of this enzyme are high, an excess of free radicals is produced that is responsible for tissue injury and elevated in HF. ${ }^{27}$ As complete blood count is commonly ordered in patients with HF and often includes automated distributions of leukocyte subsets, the ability to risk stratify a patient population with advanced HF without additional testing is attractive.

Although ejection fraction, peak oxygen, and other hemodynamic variables are classic risk factors on mortality in $\mathrm{HF},{ }^{28,29}$ we did not find associations of these variables with NLR. This may mean that the risk of death from NLR is independent of hemodynamic variables.

Our study has several limitations. First, only baseline measurements of NLR were available that made it impossible to evaluate NLR values over time and their effect on clinical outcomes. Second, we did not have information on exact causes of death, therefore we cannot further determine if inflammation is the primary driver of disease progression leading to mortality. Third, we did not have information on some potential confounders such as nutritional status or concomitant inflammatory conditions or acuity of disease; however, we had a large number of other relevant confounding variables that served for adjustment in multivariate models. Finally, this study was conducted at a single center with high expertise in the management of severe HF and our experience may not necessarily translate to those without our wide range of advanced therapeutic options.

\section{Disclosures}

The authors have no conflicts of interest to disclose.

1. Ommen SR, Hammill SC, Gibbons RJ. The relative lymphocyte count predicts death in patients receiving implantable cardioverter defibrillators. Pacing Clin Electrophysiol 2002;25:1424-1428.

2. Ommen SR, Hodge DO, Rodeheffer RJ, McGregor CG, Thomson SP, Gibbons RJ. Predictive power of the relative lymphocyte 
concentration in patients with advanced heart failure. Circulation 1998;97:19-22.

3. Balta S, Demirkol S, Unlu M, Arslan Z, Celik T. Neutrophil to lymphocyte ratio may be predict of mortality in all conditions. $\mathrm{Br} \mathrm{J}$ Cancer 2013;109:3125-3126.

4. Bhat T, Teli S, Rijal J, Bhat H, Raza M, Khoueiry G, Meghani M, Akhtar M, Costantino T. Neutrophil to lymphocyte ratio and cardiovascular diseases: a review. Expert Rev Cardiovasc Ther 2013;11: $55-59$.

5. Ijsselmuiden AJ, Musters RJ, de Ruiter G, van Heerebeek L, AlderseBaas F, van Schilfgaarde M, Leyte A, Tangelder GJ, Laarman GJ, Paulus WJ. Circulating white blood cells and platelets amplify oxidative stress in heart failure. Nat Clin Pract Cardiovasc Med 2008;5: $811-820$.

6. Uthamalingam S, Patvardhan EA, Subramanian S, Ahmed W, Martin W, Daley M, Capodilupo R. Utility of the neutrophil to lymphocyte ratio in predicting long-term outcomes in acute decompensated heart failure. Am J Cardiol 2011;107:433-438.

7. Tasal A, Erturk M, Uyarel H, Karakurt H, Bacaksiz A, Vatankulu MA, Turfan M, Sonmez O, Erdogan E, Ergelen M. Utility of the neutrophil to lymphocyte ratio for predicting in-hospital mortality after levosimendan infusion in patients with acute decompensated heart failure. J Cardiol 2013;63:418-423.

8. Park JJ, Jang HJ, Oh IY, Yoon CH, Suh JW, Cho YS, Youn TJ, Cho GY, Chae IH, Choi DJ. Prognostic value of neutrophil to lymphocyte ratio in patients presenting with ST-elevation myocardial infarction undergoing primary percutaneous coronary intervention. Am J Cardiol 2013;111:636-642.

9. Oncel RC, Ucar M, Karakas MS, Akdemir B, Yanikoglu A, Gulcan AR, Altekin RE, Demir I. Relation of neutrophil-to-lymphocyte ratio with GRACE risk score to in-hospital cardiac events in patients with ST-segment elevated myocardial infarction. Clin Appl Thromb Hemost 2013. http://dx. doi.org/10.1177/1076029613505763; in press (27 September 2013).

10. Lee GK, Lee LC, Chong E, Lee CH, Teo SG, Chia BL, Poh KK. The long-term predictive value of the neutrophil-to-lymphocyte ratio in Type 2 diabetic patients presenting with acute myocardial infarction. QJM 2012;105:1075-1082.

11. Cho KH, Jeong MH, Ahmed K, Hachinohe D, Choi HS, Chang SY, Kim MC, Hwang SH, Park KH, Lee MG, Ko JS, Sim DS, Yoon NS, Yoon HJ, Hong YJ, Kim KH, Kim JH, Ahn Y, Cho JG, Park JC, Kang JC. Value of early risk stratification using hemoglobin level and neutrophil-to-lymphocyte ratio in patients with ST-elevation myocardial infarction undergoing primary percutaneous coronary intervention. Am J Cardiol 2011;107:849-856.

12. Azab B, Zaher M, Weiserbs KF, Torbey E, Lacossiere K, Gaddam S, Gobunsuy R, Jadonath S, Baldari D, McCord D, Lafferty J. Usefulness of neutrophil to lymphocyte ratio in predicting short- and long-term mortality after non-ST-elevation myocardial infarction. Am J Cardiol 2010;106:470-476.

13. Tamhane UU, Aneja S, Montgomery D, Rogers EK, Eagle KA, Gurm HS. Association between admission neutrophil to lymphocyte ratio and outcomes in patients with acute coronary syndrome. Am J Cardiol 2008; 102:653-657.

14. Nunez J, Nunez E, Bodi V, Sanchis J, Minana G, Mainar L, Santas E, Merlos P, Rumiz E, Darmofal H, Heatta AM, Llacer A. Usefulness of the neutrophil to lymphocyte ratio in predicting long-term mortality in ST segment elevation myocardial infarction. Am J Cardiol 2008;101: 747-752.

15. Gazi E, Bayram B, Gazi S, Temiz A, Kirilmaz B, Altun B, Barutcu A. Prognostic value of the neutrophil-lymphocyte ratio in patients with
ST-elevated acute myocardial infarction. Clin Appl Thromb Hemost 2013. http://dx.doi.org/10.1177/1076029613492011; in press (9 June 2013).

16. Muhmmed Suliman MA, Bahnacy Juma AA, Ali Almadhani AA, Pathare AV, Alkindi SS, Uwe Werner F. Predictive value of neutrophil to lymphocyte ratio in outcomes of patients with acute coronary syndrome. Arch Med Res 2010;41:618-622.

17. Duffy BK, Gurm HS, Rajagopal V, Gupta R, Ellis SG, Bhatt DL. Usefulness of an elevated neutrophil to lymphocyte ratio in predicting long-term mortality after percutaneous coronary intervention. Am J Cardiol 2006;97:993-996.

18. Erkol A, Oduncu V, Turan B, Kiliçgedik A, Karabay CY, Akgün T, Güler A, Pala S, Kirma C. Neutrophil to lymphocyte ratio in acute STsegment elevation myocardial infarction. Am J Med Sci 2014;348: $37-42$.

19. Kaya A, Kaya Y, Topcu S, Gunaydin ZY, Kurt M, Tanboga IH, Kalkan K, Aksakal E. Neutrophil-to-lymphocyte ratio predicts contrastinduced nephropathy in patients undergoing primary percutaneous coronary intervention. Angiology 2014;65:51-56.

20. Kaya MG, Akpek M, Lam YY, Yarlioglues M, Celik T, Gunebakmaz O, Duran M, Ulucan S, Keser A, Oguzhan A, Gibson MC. Prognostic value of neutrophil/lymphocyte ratio in patients with ST-elevated myocardial infarction undergoing primary coronary intervention: a prospective, multicenter study. Int J Cardiol 2013;168:1154-1159.

21. Arruda-Olson AM, Reeder GS, Bell MR, Weston SA, Roger VL. Neutrophilia predicts death and heart failure after myocardial infarction: a community-based study. Circ Cardiovasc Qual Outcomes 2009:2:656-662.

22. Karabinos I, Koulouris S, Kranidis A, Pastromas S, Exadaktylos N, Kalofoutis A. Neutrophil count on admission predicts major in-hospital events in patients with a non-ST-segment elevation acute coronary syndrome. Clin Cardiol 2009;32:561-568.

23. Acanfora D, Gheorghiade M, Trojano L, Furgi G, Pasini E, Picone C, Papa A, Iannuzzi GL, Bonow RO, Rengo F. Relative lymphocyte count: a prognostic indicator of mortality in elderly patients with congestive heart failure. Am Heart J 2001;142:167-173.

24. Huehnergarth KV, Mozaffarian D, Sullivan MD, Crane BA, Wilkinson CW, Lawler RL, McDonald GB, Fishbein DP, Levy WC. Usefulness of relative lymphocyte count as an independent predictor of death/urgent transplant in heart failure. Am J Cardiol 2005;95:1492-1495.

25. Levy WC, Mozaffarian D, Linker DT, Sutradhar SC, Anker SD, Cropp AB, Anand I, Maggioni A, Burton P, Sullivan MD, Pitt B, Poole-Wilson PA, Mann DL, Packer M. The Seattle Heart Failure Model: prediction of survival in heart failure. Circulation 2006;113:1424-1433.

26. Mozaffarian D, Anker SD, Anand I, Linker DT, Sullivan MD, Cleland JG, Carson PE, Maggioni AP, Mann DL, Pitt B, Poole-Wilson PA, Levy WC. Prediction of mode of death in heart failure: the Seattle Heart Failure Model. Circulation 2007;116:392-398.

27. Tang WH, Tong W, Troughton RW, Martin MG, Shrestha K, Borowski A, Jasper S, Hazen SL, Klein AL. Prognostic value and echocardiographic determinants of plasma myeloperoxidase levels in chronic heart failure. J Am Coll Cardiol 2007;49:2364-2370.

28. Cahalin LP, Mathier MA, Semigran MJ, Dec GW, DiSalvo TG. The six-minute walk test predicts peak oxygen uptake and survival in patients with advanced heart failure. Chest 1996;110:325-332.

29. Curtis JP, Sokol SI, Wang Y, Rathore SS, Ko DT, Jadbabaie F, Portnay EL, Marshalko SJ, Radford MJ, Krumholz HM. The association of left ventricular ejection fraction, mortality, and cause of death in stable outpatients with heart failure. J Am Coll Cardiol 2003;42: $736-742$. 